\title{
ASPECTOS PENAIS DA ALIENAÇÃO FIDUCIÁRIA EM GARANTIA
}

\author{
Guilherme Guimarães Feliciano \\ Aluno do Curso de Graduação da Faculdade de Direito da USP
}

Resumo:

No Brasil, comumente o legislador introduz infrações penais em leis não-penais (principalmente em leis comerciais, civis e financeiras). Essa prática não é recomendável, porque o tratamento legal torna-se caótico; de fato, trata-se de um empecilho para juízes e intérpretes, ao analisarem casos concretos.

A alienação fiduciária em garantia, um instituto tipicamente brasileiro, evidencia esse tipo de problema. Embora estabelecida por uma lei financeira (Lei n. 4.728/65), sua disciplina legal compreende um crime, definido como a transferência ou oneração fraudulenta de bens anteriormente transferidos para o credor fiduciário.

Sendo assistemática a descrição desse crime, algumas dúvidas são inevitáveis: qual é exatamente a conduta típica? E quanto ao elemento subjetivo - é possível cometer-se esse crime na modalidade culposa? Poderia o intérprete admitir, no caso, o erro de ilicitude, ou há outra hipótese admissível se o devedor não conhece os efeitos que decorrem de uma alienação fiduciária? E qual é a relação entre esse crime e a apropriação indébita, definida como o assenhoreamento fraudulento da propriedade alheia por quem tem sua posse legítima? Nosso propósito é responder a todas essas questões no presente trabalho.

Discutir o mencionado crime é realmente importante na atualidade: financiamentos e empréstimos, no âmbito dos negócios industriais, tendem a crescer, provavelmente como resultado da política econômica brasileira. Mais empréstimos significam mais alienações fiduciárias, para garantir os respectivos créditos; conseqüentemente, haverá mais problemas penais acerca da temática chegando aos tribunais do país.

Abstract:

In Brazil, legislators commonly insert criminal infractions in no criminal acts (mainly in commercial, civil or financial acts). This practice is not recommendable, because legal treatment becomes chaotic; in fact, this is a hindrance to judges and interpreters when analysing a factual case.

The fiduciary transfer of ownership, a typical Brazilian institute, shows this kind of trouble. Although established by a financial act (4.728/65), its legal discipline comprehends a crime, described in that act as a debtor's fraudulent transferring or burdening of goods after having already transferred them to the fiducial creditor.

Being the description of this crime not systematic, some doubts are unavoiable: what is exactly the actus reus? And what about the mens rea 
- is it possible for one to commit this crime unintentionally? Could the interpreter admit, in this case, mistake of criminal law, or is there another hypothesis if the debtor does not know the effects of fiduciary transfer? And what is the relationship between this crime and embezzlement, defined as the fraudulent conversion of the property of another by one who has lawful possession of the property? We aim at answering all these questions in this project.

Discussing the crime mentioned above is really important nowadays: financings and loans in industrial areas tend to increase, probably as a result of Brazilian economical policy. The more loans, the more fiduciary transfers to guarantee credits; consequently, there will be more criminal cases corcerning this matter arriving to national courts.

Unitermos: Lei n. 4.728/65 - alienação fiduciária, credor fiduciário.

\section{Introdução}

Embora não seja recomendável que tipos penais estejam inseridos em diplomas legais voltados ao tratamento de assuntos diversos, que refujam ao próprio Direito Penal, essa prática tem-se tornado comum em nosso país. Com efeito, há infrações penais previstas, verbi gratia, na Lei n. 8.078/90, que dispõe sobre a proteção ao consumidor (proteção essa em seu sentido mais amplo, abrangendo aspectos civis, mercantis e criminais); na Lei n. 8.069/90, que dispõe sobre o Estatuto da Criança e do Adolescente; na Lei n. 8.245/91, Lei do Inquilinato; e mesmo no decreto regulamentador da Lei n. 8.212, que trata do custeio da previdência social, o que nos causa alguma espécie. Manoel Pedro Pimentel, ${ }^{1}$

1. Manoel Pedro Pimentel, Direito Penal Econômico, $1^{\text {a }}$ ed., São Paulo, Revista dos Tribunais, pp. 32-36, in verbis:

"A Revolução de 1964, que lançou o Brasil em uma nova era, acelerando o processo do desenvolvimento, teve de pagar o tributo devido pela rapidez com que se operaram as transformações, especialmente em função da nova filosofia econômico-financeira adotada.

"Vale notar, também, que os juristas não estavam adequadamente preparados para acompanhar o impulso dado nesse campo, em razão de diversos fatores, mas principalmente pelo afastamento dos estudos sistemáticos de economia. As Faculdades de Direito sempre mantiveram em seus currículos a cadeira de Economia Política. No entanto, tomando o exemplo da minha geração de estudantes, da década de 40, a formação dada nesse setor foi precária, pois a doutrina ensinada ainda se baseava no laissez-faire, laissez-passer, com os ingredientes do liberalismo da Adam Smith.

"Ora, coube, então, aos economistas, par droit de conquête, liderar esse importante setor da Revolução que era a edição das leis criadoras dos instrumentos da nova ordem jurídica. Ressentiamse, no entanto, da mesma falha de não terem recebido adequada formação para elaborar leis. Técnicos, precisos, objetivos, falando uma linguagem rica em expressões novas - a que o povo 
cuidando dos crimes econômicos, já nos advertia quanto a isto, evidenciando que tamanha assistematicidade prejudica o labor dos operadores jurídicos, pela dificuldade em se localizar os diversos preceitos, e também pela própria técnica utilizada nas respectivas redações, deficientes e lacunosas, como seria de se esperar quando são elaboradas por pessoas pouco afeitas à área criminal.

Contudo, a Lei n. 4.728/65, diploma de caráter financeiro que introduziu em nosso ordenamento jurídico o controverso instituto da alienação fiduciária em garantia, não logrou desviar-se desse pequeno inconveniente, sendolhe inserto, no art. 66, o $\S 10$ : "O devedor que alienar, ou der em garantia a terceiros, coisa que já alienara fiduciariamente em garantia, ficará sujeito à pena prevista no art. $171, \S 2^{\circ}$, inciso I, do Código Penal" Posteriormente, o Decreto-lei n. 911, que disciplinou os aspectos processuais da figura em tela, trasladou essa mesma redação para o $\S 8^{\circ}$ do art. 66 , sem contudo alterá-lo. Embora não seja esse o objetivo da presente exposição, convém preliminarmente conceituar o instituto sub foco, o que fazemos nestes termos: a alienação fiduciária em garantia é um contrato dispositivo causal de direito das coisas apto a gerar um direito real de garantia sui generis (a propriedade fiduciária), pelo qual o devedor fiduciante transfere ao credor fiduciário o domínio resolúvel de uma coisa móvel a título de garantia de uma dívida subjacente, conservando porém a posse direta sobre o bem, e apenas recuperando sua propriedade com o adimplemento de referida divida.

Conhecidos, pois, os caracteres fundamentais da figura em análise, retomemos a abordagem penal. Diz o art. $171, \S 2^{\circ}$. I, do Código Penal incorrer nas mesmas penas do estelionato (reclusão, de um a cinco anos, e multa) quem vende, permuta, dá em pagamento, em locação ou em garantia coisa alheia como própria. De imediato, tem-se uma dúvida: o art. $66, \S 8^{\circ}$, da Lei n. 4.728/65 (supratranscrito)

\footnotetext{
batizou de economês - os economistas se viram na contingência de legislar, embora não estivessem preparados para isso.

"No campo específico da sua ciência desenvolveram idéias básicas de alto nível, é força reconhecer, impondo-as aos poucos com acentuada determinação e organicidade. No entanto, o fizeram através de leis imperfeitamente redigidas $e$ defeituosamente concebidas, que demandavam correçōes tão-logo publicadas. Ao chamado mal do "bacharelismo" sucedeu-se o mal do "economismo". Não raro se constatou que, editada uma lei, tornava-se necessário interpretá-la através de outras normas complementares, sobrevindas sob as formas de regulamentos, instruções, avisos e portarias.

(...)

"Esses defeitos da legislação sobre delitos econômicos, ainda que compreensíveis, são graves. Os princípios estabelecidos pela dogmática penal são frutos de sazonadas conquistas da ciência e não podem ser postergados sem penosas conseqüências de direito.
} 
emprega apenas os verbos "alienar" e "dar em garantia", e reporta-se ao art. $171, \S$ $2^{\circ}$ : I do $\mathrm{CP}$, que além desse último apresenta mais outros quatro núcleos: vender, permutar, dar em pagamento (esses três passíveis de serem compreendidos no gênero "alienar") e dar em locação - nesse caso, não se pode falar em "alienação" Quanto à elementar "coisa alheia" não resta dúvida de que se amolda à situação: embora o fiduciante seja possuidor direto do bem, não é seu proprietário; o domínio pertence ao fiduciário, tratando-se por conseguinte de bem alheio. Porém, a dúvida persiste: há algum crime se o devedor-fiduciante aluga a coisa alienada fiduciariamente a alguém, como se própria fosse?

Em verdade, há duas interpretações possíveis. A análise literal do art. $66, \S 8^{\circ}$ permite concluir que o legislador quis apenas sujeitar o infrator às penas do art. $171, \S 2^{\circ}$, I do CP ("(...) ficará sujeito à pena prevista no (...)"); assim, a descrição típica seria aquela presente no próprio $\S 8^{\circ}$, e não a constante do art. 171 , $\S 2^{\circ}$. I. Conseqüentemente, haveria apenas dois núcleos para o crime - alienar e dar em garantia - e a ação de dar em locação, prevista no crime de disposição de coisa alheia como própria, não estaria abarcada, não sendo por isto punível. Por outro lado, se o legislador quisesse apenas referir uma pena, poderia tê-lo feito diretamente sem qualquer remissão a outros diplomas; ou ainda, referir-se ao caput do art. 171, ao qual afinal vai referir-se o próprio $\S 2^{\circ}$, I do mesmo artigo. Porém, como não fez isto, preferindo reportar-se a uma determinada figura típica que, ademais, é muito semelhante à que pretendia apenar, sugere-se que talvez tenha pretendido abranger todas as condutas relacionadas no art. $171, \S 2^{\circ}, \mathrm{I}$; os núcleos do art. $66, \S 8^{\circ}$ seriam, desse modo, meramente exemplificativos.

O Direito Penal, todavia, ameaça diretamente o status libertatis dos indivíduos, motivo por que deve ser empregado como ultima ratio do Estado, aplicando-se estritamente às hipóteses expressas em lei - nulla poena, nullum crimen sine lege. A hermenêutica diz aplicar-se-lhe, em função dessas considerações, o princípio da legalidade estrita, ${ }^{2}$ noutras palavras, o aplicador deve

2. Tércio Sampaio Ferraz Júnior, Introdução ao Estudo do Direito - Técnica, Decisão, Dominação, $1^{\text {a }}$ ed., São Paulo, Atlas S.A., 1991, p. 134 [sobre o princípio da legalidade]: "Para 0 endereçado privado dos atos soberanos, significa que só o que a lei obriga ou proibe deve ser cumprido: o restante lhe é permitido. Para o emissor de atos soberanos, significa que não só deve fazer ou deixar de fazer apenas o que a lei obriga, mas também que só pode fazer o que a lei permite. É a estrita legalidade. Para que sua ação não fique absolutamente tolhida, quando não houver lei que lhe permita agir, há o princípio da discricionariedade: a lei apenas prescreve os fins a serem atingidos pelo ato soberano, deixando uma margem de opção para a escolha do meio correto. A discricionariedade, porém, não é arbitrariedade, pois o fim estabelecido não pode ser ignorado. 
cingir-se estritamente às palavras da lei, e entre uma interpretação mais larga e outra mais estrita, deve optar por essa. Assim, melhor que se tenha por consumado (ou tentado) o crime previsto no art. $66, \S 8^{\circ}$ : da Lei n. 4.728 apenas em casos de alienação (lato sensu) e dação em garantia - a despeito da referência ao art. 171, § $2^{\circ}$, I do CP. Mas, dir-se-ia, essa não foi a vontade do legislador, como bem se denota dos indícios consignados no parágrafo anterior; abeberamo-nos então, uma vez mais, na lição dos hermeneutas, para dizer que a lei (rectius: a norma jurídica), uma vez editada e vigente, ganha vida própria, devendo ser interpretada conforme os ditames da lógica jurídica e da realidade social, e independentemente do sentido que seu criador intentou imprimir-lhe; esse servirá, apenas, como orientação exegética. Daí porque se deve discrepar a mens legis da mens legislatoris; in casu, a opção mais acertada volta-se à primeira, desconsiderando a última.

Com efeito, tipificou-se um novo delito, sem nomen iuris designado na lei, e integrado na classe dos delitos de fraude; curiosa é, nesse sentido, a sugestão de Paulo Restiffe Neto, ${ }^{3}$ quanto à forma como se deve ler o art. $66, \S 8^{\circ}$, acomodando as elementares assistematicamente dispostas à melhor redação jurídicopenal:

"Disposição fraudulenta de coisa alienada fiduciariamente Alienar o devedor ou dar em garantia a terceiros coisa que já alienara fiduciariamente em garantia" $10,00^{\prime \prime}{ }^{4}$

"Pena reclusão de um a cinco anos, e multa, de Cr\$0,50 a Cr\$ II. Sujeitos ativo e passivo

Sujeito ativo desse delito será sempre o devedor fiduciante; e o sujeito passivo será o credor fiduciário, vítima da fraude perpetrada, bem como o

Para exemplificar: só se pode prender alguém ou por haver ato delituoso flagrante ou por ordem da autoridade competente: $o$ ato soberano é vinculado à estrita legalidade (...).

3. Paulo Restiffe Neto, Garantia Fiduciária, $2^{\mathrm{a}}$ ed., São Paulo, Revista dos Tribunais, 1976, pp. 338-345.

4. A Lei n. 7.209/84 cancelou, na Parte Especial do Código Penal e nas leis especiais alcançadas pelo art. 12 do $\mathrm{CP}$, quaisquer referências a valores de multas. Isso atingiu o art. $171, \S 2^{\circ}$, I, e atingiria por conseqüência também a sugestão propugnada por Restiffe, que para tomar-se impecável, no presente contexto, deverá ter extirpada de sua redação os valores monetários designados. 
"adquirente" do bem onerado pela propriedade fiduciária, ou aquele que o recebeu em garantia, caso esteja de boa-fé, e admitindo-se que o negócio perpetrado entre esse e o fiduciante tenha apresentado caráter oneroso.

Moreira Alves ${ }^{5}$ aventa a hipótese de que o credor, de posse da coisa alienada fiduciariamente, tenha-a vendido a terceiro, sem contudo ter-se verificado o inadimplemento absoluto ou relativo da obrigação, por parte do fiduciante. Como o credor, nessas condições, não dispunha da faculdade de vender o bem, a venda realizada é ineficaz em relação ao fiduciante, que uma vez adimplente recupera a propriedade ipso iure. Não há dúvidas de que, caso houvesse agido de má-fé o credor fiduciário, teria prejudicado o devedor, fraudando-lhe os interesses de forma semelhante à prevista no art. $66, \S 8^{\circ}$; contudo, evidentemente não incorreria nas penas desse artigo, porque ele prevê a hipótese inversa, na qual atua fraudulentamente o devedor. Esse preceito mostra-se iníquo em tais circunstâncias, porém não pode ser estendido de molde a abarcar também o credor que alienar ou der em garantia coisa alienada fiduciariamente, em sendo adimplente seu devedor. Novamente, impõe-se a interpretação estrita e gramatical, tão-cara aos penalistas.

Por outro lado, Moreira Alves é taxativo ao asserir que, nessa mesma hipótese, "(...) não há que se pretender enquadrar o credor no crime definido no art. 171, $2^{\circ}$, n. I, do Código Penal". Há, porém, uma situação em que, ao nosso sentir, aquele preceito penal seria aplicável. Imagine-se que o credor fiduciário, ciente de que a obrigação de seu devedor já havia sido cumprida, venda a coisa que lhe fora alienada fiduciariamente a um terceiro; imagine-se, mesmo, que por algum motivo detivesse àquele momento a posse direta sobre o bem. Alegando ser seu proprietário e valendo-se inclusive da documentação pertinente à alienação fiduciária antes avençada para emprestar veracidade às suas afirmações, logra vender a coisa àquele terceiro de boa-fé, sabendo que, desde o adimplemento da dívida efetuado pelo devedor-fiduciante, a propriedade plena da coisa lhe houvera revertido ipso iure. Agiu dolosamente, intentando fraudar as relações mantidas com seu ex-devedor e com o adquirente de boa-fé; induzindo esse último em erro, ter-lhe-á ocasionado prejuízo patrimonial, tão-logo o atual proprietário venha a apoderar-se do bem que lhe pertence, e para a alienação do qual o ex-fiduciário não estava titulado. Embora in casu não incida a regra do art. $66, \S 8^{\circ}$, por reportar-se essa ao devedor que aliena

5. José Carlos Moreira Alves, Da Alienação Fiduciária em Garantia, $3^{2}$ ed., Rio de Janeiro, Forense, 1987, p. 234. 
o bem fiduciado, é perfeitamente admissível a aplicação das penas do art. $171, \S 2^{\circ}$, I do $\mathrm{CP}$, a cujo tipo subsume-se a situação imaginada: trata-se de um indivíduo que dispõe de coisa alheia como se própria fosse; vendera bem que sabidamente não mais lhe pertencia, desde o momento em que seu crédito foi satisfeito. Dessarte, contrariamente ao que ponderara Moreira Alves, entendemos ser cabível, nessa hipótese, o "enquadramento" da conduta do credor no crime definido pelo art. $171, \S$ $2^{\circ}$, I; incabível, sim, seria aplicar-lhe as sanções do art. $66, \S 8^{\circ}$

\section{Elemento material}

O elemento material do tipo consiste em alienar ou dar em garantia, por qualquer forma, coisa que fora já alienada fiduciariamente. Como visto, não inclui a forma "dar em locação" prevista no art. 171, $\S 2^{\circ}$, I do CP Porém, o verbo "alienar", particularmente, abrange uma série de condutas, pois significa tornar alheio, ceder, transferir a qualquer título; abrange, por conseguinte, contratos onerosos e gratuitos, tais como a compra e venda, a doação, a dação em pagamento, a permuta, etc. Já o núcleo do tipo "dar em garantia" abarca as situações que a doutrina reconhece como modalidades de começo de alienação: os direitos reais de garantia. Assim, se o devedor-fiduciante empenha a coisa alienada fiduciariamente, incorre nas sanções do art. $66, \S 8^{\circ}$; a princípio, o mesmo não pode ser dito acerca da hipoteca e da anticrese, que por definição legal devem incidir sobre imóveis, o que as torna incompatíveis com a hipótese $s u b$ foco, vez que apenas podem ser alienados fiduciariamente bens móveis (art. 66, caput, da Lei n. 4.728). Nada obstante, a legislação permite que embarcações e aeronaves sejam objetos de alienação fiduciária em garantia (cf. art. 48 do DL n. 413/69); tais bens, como se sabe, não têm aptidão para serem empenhados, e sim para serem hipotecados, ex vi do art. 825 do Código Civil ("São suscetiveis dos contratos de hipoteca os navios, posto que ainda em construção") e do art. 138 da Lei n. 7.565/86 (Código Brasileiro de Aeronáutica). Isto significa que, no caso específico das aeronaves e navios alienados fiduciariamente, incorre nas penas do art. 66, $\S 8^{\circ}$ da Lei n. 4.728 o devedorfiduciante que hipotecar esses mesmos bens. Aliás, semelhante assertiva não deve trazer perplexidade, visto que ora se analisam os aspectos penais do instituto; em sede de Direito Penal, as ficções jurídicas consagradas pelo Direito Privado não têm lugar, pois está em jogo o bem máximo do cidadão, qual seja a sua liberdade. Não é por outra razão que, exempli gratia, a doutrina penal clássica abomina a idéia de que 
se possa imputar infrações penais a uma pessoa jurídica (com esteio na Teoria da Ficção, pela qual Savigny buscou explicar o fenômeno das pessoas jurídicas); as pessoas morais, como dizem, não possuem capacidade de conduta (entendida essa como o agir/omitir humano), capacidade de culpa ou capacidade de pena. Da mesma forma, tendem a admitir o furto e o roubo (que por definição têm por objeto material uma coisa móvel) de bens que, sob a óptica do Direito Civil, são imóveis por destinação ou acessão. Nessa medida, conclui-se que navios e aviões, por natureza móveis, devem assim ser considerados na seara do Direito Penal, malgrado o tratamento que lhes é dado pelos civilistas, equiparando-os para diversos efeitos aos bens imóveis.

Se o devedor-fiduciante alienar fiduciariamente, por uma segunda vez, o bem que antes alienara nessas mesmas condições, também estará incurso no dispositivo sub foco, subsumindo-se sua conduta ao verbo "alienar" ou à locução "dar em garantia" conforme se conceba a propriedade fiduciária como uma mera propriedade resolúvel (art. 647 e $628 \mathrm{CC}$ ), solução que temos por equivocada, ou como um direito real de garantia, com maior acerto.

$\mathrm{O} \S 1^{\circ}$ do art. 66 dispõe que o arquivamento, por cópia ou microfilme, do instrumento da alienação fiduciária no Registro de Títulos e Documentos é imprescindível, sob pena de não-valer contra terceiros aquela mesma alienação; em verdade, esse registro é pressuposto para que se constitua a propriedade fiduciária, direito real de garantia que somente se conforma quando oponível perante terceiros (como, aliás, qualquer direito desse gênero: não se concebe direito real que somente vincule as partes contratantes). Consequientemente, enquanto não esteja implementado o referido registro o credor não pode ser reputado "proprietário fiduciário"; ainda não existe, efetivamente, uma propriedade fiduciária, mas apenas a propriedade plena detida pelo devedor. Indagar-se-ia então: se o devedor aliena ou dá em garantia a coisa "alienada fiduciariamente" porém antes que se processe o registro do instrumento respectivo, realiza o tipo do art. $66, \S 8^{\circ}$ ?

Paulo Restiffe Neto, ${ }^{6}$ por não imputar ao registro a função constitutiva que lhe dá José Carlos Moreira Alves, conclui necessariamente pela afirmativa: "A lei, como já vimos, determina o registro 'sob pena de não-valer contra terceiro'. Logo, sem registro valerá entre as partes. Se o devedor, investido na posse do objeto, imediatamente dele dispuser, antes de efetivado o registro por parte da

6. Paulo Restiffe Neto, Garantia Fiduciária, p. 340. 
financiadora, obviamente responderá pelo delito de 'disposição fraudulenta de coisa alienada fiduciariamente'".

Corroborando seu entendimento, colaciona acórdão da $2^{\mathrm{a}}$ Câmara Criminal do Tribunal de Justiça de São Paulo, de 13.12.72, relator o Des. Acácio Rebouças (in RT 439/361-363), com ementa nestes termos: "Estelionato Venda de coisa alheia como própria veículo objeto de alienação fiduciária - Novo certificado obtido pelo réu, ardilosamente, sem reserva de domínio Transferência daquele a terceiro Condenação mantida Inteligência do art. $171, \S 2^{\circ}, n$. II, do Código Penal" [rectius: art. 171, $\S 2^{\circ}, \mathrm{n}$. I]. Assevera o aresto: "Não importa que o título só viesse a ser registrado depois da falcatrua do apelante. Aliás, esta foi tãorápida que nem se pode atribuir desídia à financeira: 10 dias consumiu o réu desde a compra até a disposição do veículo, o que permite assentar a premeditação do golpe. O que é essencial e irremovível, neste particular, é a ciência que o réu tinha da vinculação jurídica que ele mesmo assinara. (...) Aliás, convém lembrar, a garantia da financiadora contra o creditado se inscrevia idoneamente no próprio título de emissão da firma vendedora, ou seja, na nota fiscal e na declaração de venda, à vista do que o licenciamento policial necessariamente consignaria a restrição de domínio resultante da alienação fiduciária. Foi para eliminar tal empecilho que o réu lançou mão de documentos adulterados"

$\mathrm{O}$ ânimo de adulterar documentos, in casu, tornou patente o dolo do agente, e de fato estariam presentes todos os elementos do tipo, inclusive o subjetivo (dolo), não fosse pela ausência de um deles, o que nos conduz a uma solução diversa da alvitrada por Restiffe e pelo Des. Acácio Rebouças. Trata-se do elemento normativo do tipo, objeto de nossa análise seguinte.

\section{Elemento normativo}

O tipo penal formulado pelo $\S 8^{\circ}$ do art. 66 - com técnica deficiente, repita-se - apresenta, entre suas elementares, um fator de complicação, sobretudo para a atividade do aplicador da lei. Após mencionar o sujeito ativo do crime (o devedor) e designar o chamado objeto material do crime (apenas pelo substantivo "coisa"), o tipo busca circunscrever a amplitude dessa última designação, estabelecendo tratar-se de "coisa" já alienada fiduciariamente em garantia. Isto traz alguma dificuldade ao intérprete, exigindo conhecimentos estranhos ao Direito Penal, a partir dos quais deverá ele reconhecer a ocorrência de uma alienação 
fiduciária em garantia, no caso concreto. Em outras palavras, o intérprete deverá dizer se houve uma alienação fiduciária do que se pressupõe seja o objeto material do crime; deverá dizer, ainda, a partir de quando se tinha consubstanciado essa alienação, pois o elemento temporal, aqui, implicará o reconhecimento de um crime ou a verificação de um irrelevante penal. Em alguns crimes, com efeito, muito pouco se exige do intérprete: basta uma constatação empírica, e ter-se-á por consumado o delito. Assim, por exemplo, o art. 121 do Código Penal: "matar alguém" A morte tem uma dimensão naturalística, que refoge às elucubrações interpretativas do juiz: ou a vítima está morta, ou não-está. A constatação do evento morte evoca conhecimentos de Medicina Legal, e não estritamente jurídicos; tem caráter empírico, e se consubstanciará em um laudo necroscópico (exame de corpo de delito — art. 158 e ss. do Código de Processo Penal). A atividade intelectiva do intérprete não atuará nesse particular. Noutros crimes, porém, cabe ao juiz avaliar se, in concreto, manifestou-se uma dada circunstância erigida pelo tipo penal como sua elementar; são circunstâncias desprovidas daquela dimensão naturalística, e insuscetíveis de constatação empírica. Normalmente serão conceitos jurídicos, ou standards, ou mesmo característicos morais, cuja aferição depende única e exclusivamente da atividade interpretativa do magistrado. A ele caberá pesar os diversos fatores envolvidos, e decidir pela presença ou não da elementar. Há inúmeros exemplos de crimes que possuem, em suas descrições típicas, elementares desse jaez; célebres são os arts. 215 e 216 do Código Penal (posse sexual mediante fraude e atentado ao pudor mediante fraude), que reportam-se à figura da "mulher honesta" verdadeiro standard jurídico cuja presença deverá ser aferida pelo intérprete no caso concreto. Naturalisticamente, não há como apreender a "honestidade" de uma mulher, já que esse conceito não se prende à idéia da virgindade, embora com ela guarde eventuais relações. Também o $\S 8^{\circ}$ do art. 66 da Lei n. 4.728 apresenta essa espécie de elementar: a alusão à coisa alienada fiduciariamente em garantia exige do magistrado que reconheça, na situação sub judice, a configuração de uma alienação fiduciária em garantia, bem como o momento em que se perfez. Para esse mister, lançará mão de informações hauridas nos domínios do direito privado.

Pois bem: essas elementares, cuja aferição pressupõe a atividade intelectiva e o consequiente juízo de valor do intérprete, são chamadas de elementos normativos do tipo. Sua presença não é necessária em toda e qualquer descrição típica, à diferença do que se dá com os elementos material (conduta) e subjetivo 
(dolo ou culpa); percebe-se, aliás, que geram maior complexidade para o labor do intérprete, tal qual salientado. Por isto, alguns autores, sobretudo os mais antigos, denominavam de tipos anormais aqueles que contivessem elementos normativos, contrapondo-os aos tipos normais, que deveriam trazer apenas a descrição dos elementos materiais do crime, sem qualquer menção à antijuridicidade ou à culpabilidade, e sem o emprego de elementares normativas. Bettiol opunha-se à proliferação dos tipos anormais, justamente por alargarem os poderes discricionários do juiz, concedendo maior elastério às figuras delituosas. José Frederico Marques, amparando-se em Mezger, bem define o que sejam esses elementos normativos: ${ }^{7}$ "Os elementos normativos que muitas vezes se juntam ao tipo, são aqueles componentes do tipo que exigem, para sua verificação in concreto, um juízo de valor dentro do próprio plano da tipicidade. Daí a lição de Mezger que se segue: 'Enquanto os elementos objetivos e subjetivos dizem respeito às partes integrantes do tipo penal fixadas pelo legislador descritivamente como determinados estados $e$ processos, corporais e anímicos, e, em conseqüência, hão de ser verificados caso por caso pelo juiz, cognitivamente, - nos elementos típicos "normativos" cuida-se de pressupostos do injusto típico que podem ser determinados tão-só mediante especial juizo de valor da situação de fato'". Os elementos normativos, ainda segundo o mesmo autor, podem referir-se: à antijuridicidade ("indevidamente" arts. 151; 192, I; 193, VII do CP; "sem justa causa" - arts. 153; 154; etc.; "fraudulentamente" - art. 177); a termos e expressões propriamente jurídicos ("documento"; "funcionário"; "função pública"; "coisa alheia móvel"; "alienara fiduciariamente em garantia" - art. 66. $\S 8^{\circ}$ da Lei n. 4.728); a termos e expressões extrajurídicos ("mulher honesta"; "saúde"; "dignidade"; "decoro"; etc.)

Demonstrado, por todo o dito, que o art. $66, \S 8^{\circ}$ contém um elemento normativo, explicam-se os motivos de nossa divergência para com Restiffe Neto e Acácio Rebouças. Entendem esses juristas, insistimos, que o arquivamento do instrumento da alienação fiduciária no Registro de Títulos e Documentos não tem caráter constitutivo, mas apenas probatório. Nós, porém, desposamos opinião diversa; entendemos, com Moreira Alves, ${ }^{8}$ ser esse registro dotado de propriedades 72-73.

7. José Frederico Marques, Tratado de Direito Penal, $2^{2}$ ed., São Paulo, Saraiva, 1965, $2^{\circ}$ v., pp.

8. José Carlos Moreira Alves, Da Alienação Fiduciária em Garantia, $3^{2}$ ed., Rio de Janeiro, Forense, 1987, p. 173: "Com efeito, ela [a propriedade fiduciária] nasce tão-somente do arquivamento, no Registro de Títulos e Documentos, do contrato de alienação fiduciária em 
constitutivas, pela própria natureza dos direitos reais. Com isto, e admitindo-se que "coisa já alienada fiduciariamente" seja coisa sobre a qual já incida o direito de propriedade fiduciária, não é possível sustentar que, antes das formalidades do registro, exista um bem móvel alienado fiduciariamente. Existe, sim, um bem móvel em vias de ser dessa forma alienado, e um instrumento, público ou particular, que documenta esse negócio jurídico; a propriedade fiduciária, porém, somente surgirá, oponivel erga omnes, com o arquivamento da documentação no Registro de Títulos e Documentos. Antes disto, há um contrato (ou cláusula) de alienação fiduciária em garantia, mas não uma coisa alienada fiduciariamente; é o que verifica, mutatis mutandi, quando um imóvel é vendido, sem que a escritura pública de transmissão dominial seja conduzida ao Cartório de Registro de Imóveis da respectiva circunscrição: há o contrato de compra e venda do bem de raiz, mas não há efetivamente um imóvel alienado, eis que o mesmo ainda pertence àquele que o vendera. Dessarte, anteriormente ao registro, não se verifica in concreto a elementar normativa do $\S 8^{\circ}$ do art. 66; conseqüentemente, pelo princípio da tipicidade penal, não se consuma o crime aí previsto. O elemento normativo, já o dissemos, exige a valoração do intérprete; e, valorando-o por intermédio das informações até aqui acostadas, não há como encampar a tese de Restiffe e Acácio Rebouças, que se nos assemelha tecnicamente equivocada.

Nada obsta, porém, que o devedor, em tal conjuntura, seja denunciado por infração ao art. 171 caput do $\mathrm{CP}$, eis que obteve para si vantagem ilícita, em prejuízo alheio (do credor), empregando meio fraudulento (alimentou as expectativas do credor, no sentido de torná-lo proprietário fiduciário, ao mesmo tempo em que iludiu o terceiro adquirente, não-mencionando o compromisso firmado com seu credor acerca do bem que negociara).

garantia, como o demonstramos largamente no n. 10 deste livro. Portanto, a propriedade fiduciária é sempre convencional. Não há propriedade fiduciária legal ou judicial. 


\section{Objetividade jurídica}

A objetividade material já foi aqui mencionada: trata-se da coisa alienada fiduciariamente. Já a objetividade jurídica designa o bem jurídico penalmente tutelado por intermédio da norma incriminadora. In casu, como se trata de um delito de fraude, o interesse juridicamente tutelado é a inviolabilidade patrimonial e a boa-fé nas relações jurídicas, essa última considerada não apenas em seu aspecto individual, mas sobretudo enquanto inspirada pelo interesse público de reprimir as fraudes causadoras de dano alheio. ${ }^{9}$ Buscando uma maior especificidade, podemos dizer que a objetividade jurídica encontra-se na tutela patrimonial do credor-fiduciante e na lisura das relações entre fiduciário e fiduciante. Restiffe ${ }^{10}$ expende um conceito analítico: impedir a frustração da excussão real em caso de mora ou inadimplemento do devedor, para que o credor encontre o objeto e sobre ele exerça o direito de propriedade.

No esteio da observação supratranscrita, da lavra de Magalhães Noronha, sobre a primazia do interesse público na repressão às fraudes, cabe proceder a uma oportuna consideração. A conduta típica de art. $66, \S 8^{\circ}$ pode ser realizada, sem que haja qualquer prejuízo para o credor-fiduciário. Assim será se, por exemplo, o credor-fiduciário for pontual e adimplente, pagando a totalidade das parcelas devidas, malgrado tenha já alienado o bem entregue em garantia fiduciária. A despeito da plena satisfação do crédito do fiduciário, que ipso iure extingue a propriedade fiduciária, o delito consumou-se e deverá ser punido. Pouco importa a inexistência de lesão patrimonial pois, como dito, essa não é a única objetividade jurídica do delito: impõe-se ainda a tutela da boa-fé nas relações jurídicas, cuja manutenção é de interesse público. Nesse sentido as palavras de Manzini, lembradas por Noronha: "O crime de estelionato não é considerado como um fato limitado à agressão do patrimônio de Tício ou de Caio, mas antes como manifestação de delinqüência que violou o preceito legislativo, o qual veda o servir-se da fraude para conseguir proveito injusto. (...) O estelionatário é sempre um criminoso (...) porque sua ação é, em qualquer caso, moral e juridicamente ilícita." Mutatis mutandi, o mesmo raciocínio aplica-se à disposição fraudulenta de coisa alienada fiduciariamente.

9. Cf. Magalhães Noronha, Direito Penal, $5^{\mathrm{a}}$ ed., São Paulo, Saraiva, 1969, 2ª v., pp. 359-360.

10. Paulo Restiffe Neto, Da Garantia Fiduciária, p. 341. 
Por outro lado, ademais, causas justificativas ou dirimentes devem ser previstas expressamente na lei; e tal não é o caso da pontualidade ou do adimplemento, na hipótese sob análise.

VI. Elemento subjetivo

Os crimes de fraude em geral não admitem culpa, já que o intento de enganar deve ser consciente, e voltado finalisticamente à obtenção de vantagens. Assim, tanto a figura do art. $66, \S 8^{\circ}$ da Lei n. 4.728 quanto a do art. $171, \S 2^{\circ}$ : I do $\mathrm{CP}$ admitem apenas o dolo como elemento subjetivo do tipo.

Restiffe Neto postula haver aí "dolo específico" consistente na vontade livre e consciente dirigida à prática da ação incriminadora. Ora, isto é o dolo genérico, na terminologia dos clássicos; enganou-se Restiffe no emprego da nomenclatura. Aliás, não é possível que um crime envolva apenas dolo específico, pois que esse representa uma intenção que se acha fora dos atos externos de execução do crime; ${ }^{11}$ o dolo na realização desses atos externos, todavia, está sempre presente, enquanto dolo genérico.

Inobstante, Noronha realmente entende haver no estelionato dolo específico (a doutrina mais recente denomina-o elemento subjetivo do injusto), manifestado na intenção de o agente tornar-se "dono" da vantagem, consegui-la para a submeter ao seu poder. Obtém a vantagem (dolo genérico), para assenhorear-se da mesma (dolo específico). E o agente deve ter consciência da ilicitude da desvantagem (o que se nos assemelha, mais propriamente, um elemento da culpabilidade, com arrimo na ciência penal moderna, que identifica nessa categoria jurídico-penal três elementos: a imputabilidade, a exigibilidade de conduta diversa $\mathrm{e}$ a potencial consciência da ilicitude).

Parece-nos que esse dolo específico deva ser perquirido pelo julgador também nos tipos previstos no art. $66, \S 8^{\circ}$ da Lei n. 4.728 e no art. $171, \S 2^{\circ}$, I do CP. Para condenar o devedor- fiduciante não bastará verificar sua intenção de realizar a conduta proibida (dispor da coisa alienada fiduciariamente); paralelamente a isto, dever-se-á detectar ainda o dolo específico de assenhorear-se da vantagem ilícita que decorrera da operação fraudulenta. Com esses expedientes, evita-se a condenação de incautos que não compreendem a natureza do negócio jurídico 
celebrado, e acreditam ter ainda a livre disponibilidade do bem, já que lhe mantêm a posse direta. Considerar integrada a conduta típica em casos que tais, e remeter a defesa do incauto à alegação de erro de proibição (art. 21 do CP), seria dificultar-lhe tremendamente essa defesa, em face do princípio estabelecido na primeira parte do art. 21, caput ("O desconhecimento da lei é inescusável").

\section{Consumação e tentativa}

Sua verificação a princípio não ofereceria dificuldades, não fosse pelo elemento normativo do tipo. Diz Restiffe: "Consuma-se o delito no momento da alienação fraudulenta do objeto ou da sua nova oneração em garantia. "Aqui evidentemente não se deve aguardar eventual registro (da alienação ou oneração fraudulenta) para que se tenha por consumado o delito, até porque um tal registro não seria efetuado pelo oficial público, ao constatar o registro anterior da alienação fiduciária. Basta a mera avença com terceiro, no sentido de se alienar ou dar em garantia a coisa alienada fiduciariamente, e opera-se a consumação delitiva. A intenção de fraudar e os atos executórios efetuados nesse sentido são suficientes para a configuração do crime. O legislador de 1969 que, reitere-se, não era afeito à técnica jurídico-penal, não foi suficientemente cuidadoso ao redigir o tipo, fazendo-o de forma condenável. $O \S 8^{\circ}$ diz: "O devedor que alienar, ou der em garantia a terceiros, coisa que já alienara fiduciariamente (...)" (grifamos). Se o bem fora alienado fiduciariamente em garantia, o devedor-fiduciante detém apenas uma expectativa de direito; a propriedade em si pertence ao fiduciário. Se ninguém pode transmitir mais direitos do que tem (nemo ad alium plus iuris transferre potest quam ipse habet), obviamente o devedor não poderá "alienar" ou "dar em garantia" a coisa sob garantia fiduciária. Daí porque não se deve esperar, para a consumação, a formalidade do registro, que em tese seria exigível em alguns casos, para a alienação ou dação em garantia do bem (verbi gratia, na alienação de veículo automotor, que deve ser comunicada ao Detran para que se proceda à expedição de novos documentos - C.R.V e C.R.L.V - em nome do novo titular; ou imaginando-se que a oneração fraudulenta seja ultimada como uma nova alienação fiduciária em garantia): juridicamente, essa alienação ou dação jamais se operará. A consumação, frisamos, dar-se-á com a intenção de fraudar aliada à atividade material tendente à consecução da fraude, e nada mais. 
Por outro lado, ainda que presentes esses dois requisitos, não haverá consumação, se o elemento normativo ainda não estiver integrado — ou seja, se o instrumento da alienação fiduciária original ainda não houver sido arquivado no Registro de Títulos e Documentos. É o que vimos linhas acima. Temos aqui, por conseguinte, um gênero delitual que raramente tem guarida nos ordenamentos jurídicos em geral: trata-se de um crime concursual, isto é, de um crime que necessita, para a sua configuração, da concorrência de fato(s) exterior(es) à sua descrição típica. ${ }^{12} \mathrm{O}$ exemplo usualmente empregado para a ilustração desse gênero, no Brasil, remete-nos ao DL n. 7.661/45 e aos crimes falimentares, descritos nos arts. 186 a 190 daquele diploma, e que para se consumarem pressupõem a decretação da falência do devedor, ainda que ulteriormente à realização da conduta típica (daí se falar em crimes pré-falimentares e pós-falimentares); assim, e.g., a irregular escrituração dos livros comerciais, por si só, não configura infração penal alguma, a não ser que o comerciante venha a ter sua falência decretada: nessas condições, e unicamente nelas, terá perpetrado um crime falimentar. Ora, o art. 186, VI, $2^{a}$ parte, que versa esse delito, não faz qualquer menção ao fato da falência, ao descrever a conduta típica reprovada; a doutrina, porém, é unânime em asserir que apenas estará consumado o crime falimentar si et quando o devedor comerciante vier a falir, por força de declaração judicial - fato esse que não integra o tipo legal, mas que concorre com ele, para que se tenha configurado o ilícito penal. Pois bem: com igual razão, também o delito de disposição fraudulenta de coisa alienada fiduciariamente pertence ao gênero dos crimes concursuais, em função do elemento normativo que seu tipo contém. Alienação fiduciária em garantia somente haverá com o registro do respectivo instrumento; e esse registro, embora não constante do tipo legal sub foco, é conditio sine qua non para que haja a disposição fraudulenta de um objeto efetivamente alienado em fidúcia. Dessarte, para a consumação do delito previsto no art. $66, \S 8^{\circ}$ da Lei n. 4.728 deve concorrer o fato do arquivamento do instrumento contratual no Registro de Títulos e Documentos; essa assertiva inconteste, que aparentemente não fora ainda alvitrada pela doutrina pátria, põe termo ao isolamento dos crimes falimentares enquanto insertos na categoria dos

12. Manoel Pedro Pimentel, Legislação Penal Especial, $1^{\text {a }}$ ed., São Paulo, Revista dos Tribunais, 1972, p. 83: "Chamam-se crimes concursuais aqueles que concorrem com outro ou outros fatos jurídicos estranhos à esfera do Direito Penal, incluindo-se entre eles, sem dúvida, o crime falimentar." 
crimes concursuais: doravante, deverá figurar ao seu lado o crime de que ora nos ocupamos.

A tentativa é perfeitamente admissível, na medida em que diversos atos deverão ser executados até que o terceiro seja convencido pelo fraudador, e até que os atos materiais finais da alienação ou dação em garantia fraudulenta se implementem. Não atingida a fase final, em que devedor-fiduciante e terceiro assentem na alienação ou dação em garantia, eis que interrompida por circunstâncias alheias à vontade do agente, tem-se a tentativa (art. 14, II CP).

\section{Co-autoria e participação}

Em Direito Penal, autor é quem executa a ação expressa pelo verbo típico da figura delituosa (S. Soler, Derecho Penal). Outrossim, co-autores são aqueles que, com unidade de desígnios, executam conjuntamente a ação (ou omissão) prevista no núcleo do tipo, isto é, o verbo integrante da figura típica. A participação, porém, tem caráter acessório em relação à conduta típica; o participante simplesmente colabora com o autor (ou co-autores) na realização do tipo penal, sem entretanto praticar ele próprio condutas previstas na figura típica. Frederico Marques ${ }^{13}$ considera haver, in casu, o que denomina co-delinqüência eventual: embora se verifique a participação de mais de uma pessoa para a prática de um crime, nem todas cometem atos previstos como típicos, na descrição legal da regra preceptiva. Os que não executam a ação ou omissão consubstanciadas no tipo, mas concorrem para o crime de qualquer modo (cf. art. $29 \mathrm{CP}$ ), realizam uma conduta que a princípio seria penalmente irrelevante, mas que se torna relevante em virtude de um enquadramento de subordinação ampliada: a norma do art. 29, dita norma de extensão, transforma em típica uma conduta de per si atípica.

Essa introdução se fez necessária para que pudéssemos, nesse ínterim, uma vez mais contraditar o posicionamento de Restiffe Neto, a respeito do tema em análise. Na verdade, poucos autores preocuparam-se com a abordagem dos aspectos penais da alienação fiduciária em garantia, o que nos obriga a lidar com um cabedal limitado de considerações a respeito; daí insistirmos na análise da obra de Paulo Restiffe, autor que se debruçou com particular atenção sobre a temática criminal da 
alienação fiduciária. Assevera ele, ${ }^{14}$ no tópico "co-autoria". que se o devedor nãooculta a circunstância de subsistir o gravame da alienação fiduciária em garantia, e o adquirente aceita conscientemente adquirir o objeto ou recebê-lo em garantia, estará incorrendo no delito do art. $66, \S 8^{\circ} \mathrm{em}$ co-autoria. Aqui reside o engano do nobre jurista. Há, sem dúvida, concurso de agentes; porém, não na modalidade da coautoria, como pretendido, mas na modalidade da participação. Ocorre que o terceiro de má-fé, na hipótese aventada, não realiza nenhum dos núcleos do tipo previstos no art. 66, $\S 8^{\circ}$ (alienar / dar em garantia); antes, adquire ou recebe em garantia (melhor seria dizer pretende adquirir ou receber em garantia, visto que a alienação ou a dação em garantia são impossíveis, como dito supra), fatos que configurariam irrelevantes penais, não fosse a norma de extensão do art. 29 do Código Penal. Como colaborou para a consecução do crime, responderá pela consumação desse, mas será apenado na medida de sua culpabilidade (art. 29, CP, in fine). O terceiro de má-fé deixa de ser sujeito passivo, e passa a ser partícipe.

À mesma conclusão chegamos, aliás, pela exegese do art. 31 do Código Penal, atinente a alguns casos de impunibilidade: "O ajuste, a determinação ou instigação e o auxílio, salvo disposição expressa em contrário, não são puníveis, se o crime não chega, pelo menos, a ser tentado" Entendemos, com respaldo na doutrina $^{15}$ que as hipóteses de co-delinqüência mencionadas - ajuste, determinação, instigação e auxílio - são autênticas situações de participação de um agente no delito perpetrado por outro, esse sim executor do ilícito penal, determinado, instigado ou auxiliado que fora pelo primeiro, ou ainda mediante ajuste com ele. Conforme o magistério de Paulo José da Costa Júnior, ${ }^{16}$ ajuste é o pactum sceleris, é o acordo que fazem previamente os agentes, visando a prática do crime; ora, é exatamente o que se observa no contexto sob análise: o alienante fiduciante (o autor da conduta incriminada pelo $\S 8^{\circ}$ do art. 66) e o pretenso adquirente (partícipe nesse mesmo delito) ajustam a consecução da fraude, eis que fora esse último previamente cientificado da condição do bem que tencionava possuir. Ajuste, pois, e portanto participação do terceiro adquirente; e não co-autoria.

14. Paulo Restiffe Neto, Garantia Fiduciária, p. 342.

15. Damásio Evangelista de Jesus, exempli gratia, ao comentar o art. 31 do Código Penal, inicia sua exposição com um primeiro título: "Participação impunível" Cf. Damásio E. de Jesus, Código Penal Anotado, $4^{2}$ ed., São Paulo, Saraiva, 1994, p. 117.

16. Paulo José da Costa Júnior, Comentários ao Código Penal, $1^{\text {a }}$ ed., São Paulo, Saraiva, 1986, v. 1, p. 237. 
Co-autoria, propriamente, ocorrerá em situações menos encontradiças. Um exemplo que nos vem à mente: determinada sociedade comercial, gerida por dois sócios que administram-na sem qualquer outra ingerência, adquire bem mediante financiamento, aliena-o fiduciariamente à financeira a que recorrera e, após constituída a propriedade fiduciária sobre o objeto, busca aliená-lo a terceiro, ou dálo em garantia. Em verdade, a pessoa jurídica incorreu no tipo da disposição fraudulenta de coisa alienada fiduciariamente, porque com ela negociara a sociedade financeira. Contudo, pessoas jurídicas não podem ser condenadas penalmente, porque não são aptas ao cometimento de crimes. Assim, o delito deverá ser imputado aos sócios-gerentes, que conscientes da ilicitude do fato e desejosos de sua realização, agiram dolosamente na perpetração da fraude. Como dividem os poderes de gestão, a decisão de alienar ou dar em garantia o bem fiduciado é da responsabilidade de ambos; em última análise, ambos alienaram ou deram em garantia esse bem, havendo delinqüido, portanto em co-autoria proprio sensu.

\section{Apropriação indébita}

Embora esse delito não esteja referido na Lei n. 4.728 ou no DL n. 911, a doutrina reiteradamente tem feito alusão ao mesmo. O caput do art. 66 da Lei n. 4.728 prevê que o fiduciante responderá, perante o fiduciário e a sociedade, por todas as responsabilidades e encargos que lhe incumbirem, conforme a lei civil e penal. Quanto às responsabilidades penais, resta saber se outras figuras penais, previstas no $\mathrm{CP}$, podem com certa freqüência ser realizadas pelo devedor-fiduciante enquanto tal, ou seja, no âmbito das relações fiduciárias em que está inserido e por intermédio das prerrogativas de que está investido nessa qualidade. A parte final do art. 66 caput elimina qualquer obstáculo à imputação de outros crimes, que não o do $\S 8^{\circ}$, ao fiduciante.

Raciocinando por esse viés, concluíram os autores que a apropriação indébita, tal como prevista no art. 168 do Código Penal brasileiro, poderia ser imputada ao devedor-fiduciante com grande propriedade, desde que esse se apropriasse do bem alienado fiduciariamente, tomando-o como seu, embora sem o objetivo de aliená-lo a outrem ou dá-lo em garantia. Com efeito, reza o art. 168: "Apropriar-se de coisa alheia móvel, de que tem a posse ou detenção. Pena reclusão, de um a quatro anos, e multa". O devedor-fiduciante, sem sombra de dúvidas, tem a posse direta $e$ desvigiada da coisa alheia móvel; o caráter em 
destaque permite concluir que se o fiduciante dela se apropria, incorre na figura típica do art. $168 \mathrm{CP}$ (e não na figura do art. $155 \mathrm{CP}$ — furto - pois nessa, embora se admita que o agente tenha já previamente a posse sobre a res furtiva, exige-se, sob pena de desfiguração do crime, que uma tal posse seja vigiada: verbi gratia, comete furto e não apropriação indébita o indivíduo que pede ao empregado de uma loja determinado objeto sob o pretexto de querer examiná-lo, evadindo-se com o bem solicitado tão-logo esse the seja entregue, inadvertidamente, pelo empregado).

Importa observar que, nessa hipótese (apropriação indébita), o momento do dolo é conseguinte à prestação causativa da vantagem ilícita (no caso, a assunção da posse direta sobre o bem, pelo devedor); inicialmente, recebe em confiança o bem alienado fiduciariamente, e mais tarde pretende inverter o título de sua posse, apropriando-se da coisa. Observe-se também o traço tipicamente fiduciário nessa modalidade de negócio jurídico, despontando com nitidez em meio aos aspectos penais do instituto (o que deve ser realçado, para que sobre isto ponderem os que negam qualquer caráter fiduciário à alienação fiduciária em garantia....). Ademais, essa localização do momento do dolo é valiosa, porque se um tal momento é anterior ao erro do sujeito passivo (nessas circunstâncias a conduta do fiduciário passa a ser verdadeiramente um erro, ao qual fora induzido pelos ardis do fiduciante), determinante da prestação causativa da vantagem ilícita, temos não mais uma apropriação indébita, mas um estelionato.

Além do caput do art. 168, pode-se antever, outrossim, a aplicação de uma das causas de aumento de pena desse mesmo dispositivo, mais especificamente aquela prevista no inciso I de seu $\S 1^{\circ}$. Lê-se aí que a pena é aumentada de um terço, quando o agente receber a coisa em depósito necessário. $\mathrm{O}$ depósito da Lei n. 4.728 não tem caráter consensual, podendo ser considerado como um efeito legal da propriedade fiduciária; essa, em relação àquele, terá a qualidade de um ato jurídico stricto sensu. Esse depósito é uma decorrência direta da lei, e opera-se necessariamente toda vez que credor e devedor derem causa ao surgimento da propriedade fiduciária; por isto, caracteriza-se como um depósito necessário. A figura do depósito necessário compreende o depósito legal (fazendo-se em desempenho de obrigação legal, como é o caso) e o miserável ("miserable depositum", efetuando-se por ocasião de alguma calamidade pública, como um incêndio ou inundação), como se depreende do art. 1.282, I e II, do Código Civil. A lei penal abrange essas duas modalidades, portanto abarca a hipótese do depósito legal criado pela Lei n. 4.728/65, com as alterações do DL n. 611/69. 
Dessa maneira pensam, entre outros, Ramagem Badaró ${ }^{17}$ e Paulo Restiffe Neto. Esse último, referindo-se ao bem alienado fiduciariamente do qual pretende apossar-se o credor para excutir a garantia, assevera: "Sonegando-o [o fiduciante], sem motivo justo, a permanência em seu poder configura o delito de apropriação indébita de coisa alheia ao móvel de que tinha posse em razão de depósito necessário."

Ramagem Badaró ${ }^{18}$ observa ainda que também o credor fiduciário pode ser autor do delito de apropriação indébita, embora apenas excepcionalmente. Ocorre que o fiduciário não é titular pleno e efetivo de uma propriedade, diz; tem ele a propriedade da coisa alienada apenas para fins de garantia. Somente no momento em que se realiza a condicio iuris resolutiva do contrato de alienação fiduciária (a satisfação do crédito), deixa de ser o titular dessa propriedade que lhe fora dada em garantia; e somente então, segundo Badaró, pode haver a tipificação da apropriação indébita por parte do credor fiduciário, desde que esse se recuse a devolver a coisa móvel ao fiduciante, com o fito de tê-la ou usá-la como própria. Se, porém, tratar-se de simples procrastinação, sem o animus de assenhorear-se do objeto, não há apropriação indébita por ausência do elemento subjetivo, mas apenas mero inadimplemento de obrigação contratual. Ramagem Badaró não tece maiores comentários sobre seu exemplo, o que geraria uma certa perplexidade se considerarmos que a posse direta do bem remanesce com o fiduciante, e não com o fiduciário. Porém, podemos imaginar a hipótese em que o credor requisita a posse direta da coisa para a excussão de sua garantia, ao que não resiste o devedor, entregando-a sem maiores objeções; logo a seguir, porém, purga a mora e satisfaz o crédito, revertendo-se ipso iure a propriedade do objeto para ele, devedor. Se, nesse caso, o credor - que agora detém a posse direta sobre a coisa - dela vem a apropriar-se, negando-se a devolvê-la ao seu legítimo proprietário, incorre nas penas do art. 168 caput do Código Penal (sem nenhuma causa de aumento específica, porém). Nesse contexto, portanto, é de todo admissível o comentário de Ramagem Badaró, a que nos reportamos.

17. Ramagem Badaró, Fisionomia Civil, Processual e Penal da Alienação Fiduciária em Garantia, 1ª ed., São Paulo, Juriscrédi, 1972, p. 154.

18. Ramagem Badaró, ob. cit., pp. 162-163. 
X. Conclusão

Os aspectos penais do instituto não apresentam grande dificuldade para o estudioso. Embora com técnica deficiente, e inserido em legislação que não cuida especificamente da temática penal, o $\S 8^{\circ}$ do art. 66 (Lei n. 4.728) estabeleceu um novo tipo penal, diverso inclusive daquele que aponta como paradigma (art. 171, $\S 2^{\circ}$ I do Código Penal), até porque esse último preceito abarca condutas nãomencionadas no primeiro dispositivo (v.g., dar em locação).

Divergindo de Paulo Restiffe Neto e outros, entendemos que a alienação ou dação em garantia de objeto destinado à alienação fiduciária em garantia, antes que se lhe arquive o contrato no Registro de Títulos e Documentos, não configura o crime previsto no art. $66, \S 8^{\circ}$; fundamentamos essa posição com fulcro na expressão "que já alienara fiduciariamente", elemento normativo do tipo, que não se teria verificado na hipótese em tela: sem o registro constitutivo, não há propriedade fiduciária, e portanto inexiste ainda a alienação fiduciária em garantia da coisa, propriamente dita. O que há é apenas o título apto a realizá-la. Dessarte, a consumação do delito pressupõe o registro do contrato de alienação fiduciária (ou daquele que contenha cláusula que a preveja), sem o qual não ocorrerá. Trata-se, por conseguinte, de um delito concursual, como quer a doutrina penalista: para a consumação delitual, exige-se a configuração de um fato qualquer não inserto no tipo penal, mas que é seu pressuposto lógico. $O$ exemplo clássico dessa modalidade de delito pode ser encontrado na Lei de Falências: só há crime falimentar, se houver falência decretada; não configurado esse fato, a escrituração irregular dos livros comerciais, v.g., é um irrelevante penal (cf. art. 186, VI, segunda parte, do DL n. $7.661 / 45)$.

Por outro lado, cumpre-nos esboçar, à guisa de conclusão e em traços largos, o panorama completo em que está inserto o instituto da alienação fiduciária em garantia, para que se possa então conjecturar sobre suas reais perspectivas. Devese ter em conta que, nesse país, a estrutura político-econômica hodierna, dirigida à retomada do desenvolvimento nacional e à redução das atividades econômicas encetadas pelo Estado (privatizações), prenuncia o incremento das operações de crédito, pela necessidade de injeções de capital na indústria brasileira. No mesmo sentido sinaliza o enorme índice de falências decretadas ultimamente, em decorrência das altas taxas de juros observadas no curso do plano econômico em vigor: grande a inadimplência, tanto maior a exigência de capitais. 
Com efeito, a quem competirá, prioritariamente, fornecer os recursos financeiros reclamados pela sociedade e pelo mercado, sobretudo quando grassa entre nós um regime tantas vezes acoimado de neoliberal? Evidentemente que à iniciativa privada, isto é, às sociedades financeiras, para as quais o legislador reservou, ao final da década de 60 e com vistas à utopia desenvolvimentista de então, a garantia fiduciária. Dessarte, em proliferando as linhas de crédito e os financiamentos patrocinados por tais entidades, na mesma proporção haverá de se multiplicar a casuística da alienação fiduciária em garantia - e, de igual modo, as questões relativas à sua tutela penal. Mais do que nunca, problemas desse jaez eclodirão nas cortes judiciárias - e, mais do que nunca, o intérprete judicial e o hermeneuta deverão ter respostas seguras e expeditas, sob pena de se comprometer levianamente a liberdade dos cidadãos, bem de máxima hierarquia nos Estados Democráticos de Direito.

São Paulo, janeiro de 1996. 